XIX

Papers of the

Bibliographical Society

of Canada

I980

Cahiers de la

Société bibliographique

du Canada

The Bibliographical Society of Canada La Société bibliographique du Canada Toronto, Canada I98I 



\section{Table of Contents / Table des matières}

Editorial Note / Préliminaire 4-5

Our Contributors / Nos collaborateurs 6

Minutes of the I980 Annual Meeting of the Society 7

F.R. Scott: A Canadian in the Twenties. SANDRA DJWA II

Paper Evidence in Toronto Imprints, 1798 to I84I

PATRICIA LOCKHART FLEMING 22

The Publishing History of W.H. Smith's Canada: Past, Present and Future: A Preliminary Investigation. PATRICIA STONE 38

Canadian Periodicals and Intellectual History: The Case of the McGill University Magazine/University Magazine, I90I-I920 PETER F. MCNALLY $\quad 69$

An Index to the Literary Garland Updated. MARY LU MACDONALD 79

Books in Review. WILLIAM F.E. MORLEY $\quad 84$

$\begin{array}{ll}\text { Books Received } & \text { I26 }\end{array}$

$\begin{array}{ll}\text { Means and Purposes: A suggestion to our members and friends } & \text { I27 }\end{array}$ 